\title{
ARTYKutY
}

Klio. Czasopismo poświęcone dziejom Polski i powszechnym

PL ISSN 1643-8191, t. 50 (3)/2019, s. 3-17

(c) $(1)$

http://dx.doi.org/10.12775/KLIO.2019.023

IRENEUSZ MILEWSKI"

\section{Alexander redivivus? Opis solida z wizerunkiem Konstantyna Wielkiego w Vita Constantini ${ }^{* * *}$}

\author{
Alexander redivivus? The description \\ of a solidus with the image of Constantine \\ the Great in Vita Constantini $(\mathrm{IV}, 15)$
}

Streszczenie. W tekście poddano analizie passus z Vita Constantini (IV,15). W opinii autora relacji, Euzebiusza z Cezarei, przedstawia on oddanego religii chrześcijańskiej i pogrążonego w modlitwie Konstantyna Wielkiego. Do naszych czasów dochowały się liczne warianty solida z awersem opisanym przez Euzebiusza z Cezarei. Identyczne przedstawienie było również bite na brązowym i srebrnym pieniądzu cesarza Konstantyna, jak również na pieniądzu opatrzonym wizerunkiem jego synów ze związku z Faustą (cezarów Konstantyna, Konstancjusza oraz Konstansa) oraz ich kuzyna Delmacjusza. Analizując ikonografię pieniądza, należy również wziąć pod uwagę przedstawienie z rewersu. Stanowi

Zakład Historii Starożytnej, Instytut Historii Uniwersytetu Gdańskiego, ul. Wita Stwosza 55, 80-952 Gdańsk, hisim@univ.gda.pl, ORCID: 0000-0001-5743-8060.

* Artykuł powstał w ramach prac nad projektem finansowanym przez Narodowe Centrum Nauki (UMO-2015/17/B/HS3/00135). 
ono uzupełnienie propagandowego przekazu zasygnalizowanego na awersie. W przypadku opisanego solida przedstawienia te mają co prawda charakter religijny, przede wszystkim jednak manifestują potęgę militarną Imperium Rzymskiego. Opisane przez autora Vita Constantini przedstawienie nie było nowe w numizmatyce antycznej. Nawiązywało ono do przedstawień Aleksandra Wielkiego (na tzw. koinonach z okresu wczesnego cesarstwa) oraz tych władców hellenistycznych, którzy rościli pretensje do panowania nad Wschodem. Prawdopodobnie nie inaczej jest również w przypadku analizowanego przedstawienia cesarza Konstantyna. Pojawia się ono na pieniądzu bitym po 324 roku, kiedy cesarz dopiero co pobiwszy Licyniusza oraz opanowawszy prowincje na Wschodzie, zamierzał również stawić czoła perskiemu zagrożeniu. Jednym z elementów tej polityki było przedstawienie siebie, swych synów (ze związku z Faustą) oraz kuzyna Delmacjusza jako „nowych Aleksandrów”. Autor artykułu, analizując powyższy opis, wskazał również na błędne tłumaczenie interesującego go passusu na język polski oraz na inne języki nowożytne (niemiecki i francuski). Najprawdopodobniej źródłem tego błędu było zasugerowanie się tłumaczeniem analizowanej relacji na łacinę, jakie odnajdujemy w Patrologia Graeca.

Abstract. The text analyses the description of a solidus presenting Constantine the Great engrossed in prayer. According to the author of the report, presenting the emperor with the uplifted eyes was meant to prove his piety. Numerous variants of solidi described by the author Vita Constantini (IV, 15), have survived to the present day. Identical image of the reverse was also minted on emperor Constantine's bronze coins, as well as bronze and silver coins of his sons and cousin. When analysing iconography of coinage, one should also take into consideration the image of the reverse, which supplements the propaganda message revealed on the obverse. In the case of the described solidus, the imagery is not only of religious nature but it shows also the military power of the Roman Empire. The imaging described by Eusebius of Caesarea was no novelty in ancient numismatics. It drew upon the depiction of Alexander the Great and some other Hellenic kings, who claimed the right to rule in the East. It is no different in the case of the analysed portrayal of the emperor Constantine. It is shown on the coins issued after 324, when the emperor, having defeated Licinius, had to face the Persian threat. One of the elements of this policy was portraying himself, his sons (Constantine, Constantius and Constans) and nephew (Delmatius) as "new Alexanders". Analysing the above description, the author of the article also points to the erratic translation of the text into Polish and into others modern languages (German and French). The source of the mistake probably was the interference of the Latin translation as found in Patrologia Graeca.

Słowa kluczowe: Konstantyn Wielki, późna starożytność, wczesne Bizancjum, numizmatyka antyczna i wczesnobizantyńska

Keywords: Constantine the Great, late antiquity, early Byzantium, ancient and early Byzantine numismatics 
$\mathrm{M}$ oneta z wielu względów stanowi cenne źródło poznania historycznego. Nie inaczej jest również w przypadku antycznych numizmatów oraz eksponowanych na nich treści propagandowych. Składają się na nie inskrypcje oraz przedstawienia ikonograficzne. Obydwa elementy stanowią całość komunikatu, jaki chciano upowszechnić pomiędzy mieszkańcami Imperium, a nawet poza jego granicami. Ikonografia pieniądza, a już tym bardziej pojawiające się nań inskrypcje rzadko jednak interesowały autorów starożytnych ${ }^{1}$, choć i w tej mierze odnotowujemy wyjątki, jak chociażby wzbudzający negatywne emocje u autorów chrześcijańskich cesarz Julian oraz propagowany przez niego, także na bitym pieniądzu, program nowego porządku politycznego i religijnej odnowy społeczeństwa w duchu politeizmu². Jako że relacji opisujących antyczne numizmaty jest niewiele, tym bardziej warto przyjrzeć się przekazom, jakie na ten temat odnajdujemy w Vita Constantini, dziele przypisywanym Euzebiuszowi z Cezarei ${ }^{3}$. Autor

1 Por. I. Milewski, Nomismaton eikones. Theodoret of Cyrus on Iconography of Money, [w:] Emas non quod opus est, sed quod necesse est: Beiträge zur Wirtschafts, Sozial, Rezeptions und Wissenschaftsgeschichte der Antike. Festschrift für Hans Joachim Drexhage zum 70. Geburtstag, Hrsg. von K. Ruffing, K. Dross-Krüpe, Wiesbaden 2018, s. 339-344.

2 Socrates, Historia Ecclesiastica III, 17. Por. także K. Eyling, „Wer wird jetzt noch an Schicksalsforschung und Horoskop glauben?" (Ephraim der Syrer 4, 26). Bemerkungen zu Julians Stiermünzen und zum Geburtsdatum des Kaisers, „Jahrbuch für Numismatik und Geldgeschichte” 2005-2006, t. 55-56, s. 111-119.

3 Autorstwo Vita Constantini nie jest kwestią oczywistą. Nie mam najmniejszej wątpliwości, że tekst w wersji znanej nam obecnie nie wyszedł spod pióra zmarłego w $339 \mathrm{r}$. Euzebiusza, biskupa Palestyńskiej Cezarei. Najprawdopodobniej powstał on nie wcześniej jak u schyłku IV w. (w czasach Teodozjusza Wielkiego), a niewykluczone że jeszcze później, w okresie propagowania w Cesarstwie Bizantyńskim kultu cesarza Konstantyna. Dyskusja na temat chronologii powstania Vita Constantini oraz jego wartości poznawczych ma ogromną literaturę, por. między innymi: H. Grégoire, La „conversion” de Constantin, „Revue de l'Université de Bruxelles” 1930-1931, t. 36, s. 231-272; idem, Eusèbe n'est pas l'auteur de la "Vita Constantini” dans sa forme actuelle, et Constantin ne s'est pas "converti” en 312, „Byzantion” 1938, t. 13, s. 561-583; F. Vittinghoff, Eusebius als Verfasser der Vita Constantini, „Rheinisches Museum” 1956, t. 96, s. 330-373; F. Winkelmann, Zur Geschichte des Authenzititätsproblems des Vita Constantini, „Klio. Beiträge zur Alten Geschichte" 1962, t. 11, s. 187-243; T. D. Barnes, Constantine and Eusebius, Cambridge 1982, s. 265-271; T. G. Elliot, Eusebian Frauds in the Vita Constantini, „Phoenix” 1991, t. 45, s. 162-171; K. M. Giradet, Die Konstantinische Wende. Voraussetzungen und geistige 
interesującego nas tu tekstu przekazał opisy trzech numizmatów epoki konstantyńskiej, a mianowicie solida z popiersiem Heleny (z Helena pacifera na rewersie, przedstawienie opatrzone inskrypcją: SECVRITAS REI PVBLICAE $)^{4}$, pośmiertnej emisji przedstawiającej Konstantyna Wielkiego, który niczym Sol invictus wzbija się w kwadrydze ku wyciągniętej do niego dextera $D e i^{5}$, oraz solida przedstawiającego cesarza ze wzrokiem uniesionym ku górze, w pozie powszechnie uchodzącej, także w starożytności, za modlitewną. Analiza tego ostatniego przekazu, skonfrontowana z ikonografią antycznych numizmatów, w tym przede wszystkim monet epoki konstantyńskiej, będzie przedmiotem poniższych rozważań.

\section{Opis solida w relacji Euzebiusza z Cezarei}

Interesujący nas opis odnajdujemy w 15 rozdziale IV księgi Vita Constantini. Czytamy w nim:

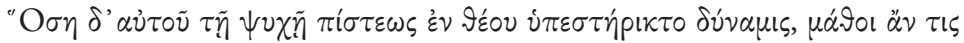

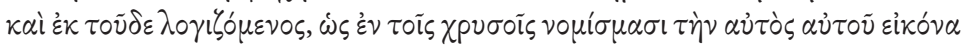

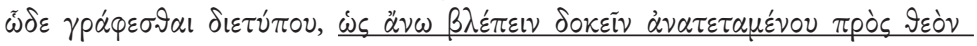

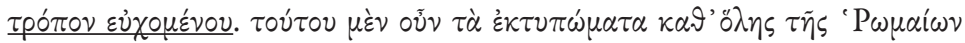

Grundlagen der Religionspolitik Konstantins des Großen, Darmstadt 2006; K.M. Girardet, Der Kaiser und sein Gott. Das Christentum im Denken und in der Religionspolitik Konstantins des Großen, Berlin 2010; B. Bleckmann, Einleitung, [w:] Eusebius von Caesarea, De vita Constantini/Über das Leben Konstantins, Turnhout 2007, s. 7-106.

${ }^{4} \mathrm{Na}$ temat tego numizmatu por. I. Milewski, Flavia Iulia Helena. Kilka uwag na temat ideologicznych aspektów mennictwa epoki konstantyńskiej, [w:] Florilegium historicum amicorum munera: profesorowi Krzysztofowi Maciejowi Kowalskiemu w sześćdziesiata piąta rocznicę urodzin przyjaciele, koledzy, uczniowie, red. T. Maćkowski, Gdańsk 2016, s. 303-319.

${ }_{5} \mathrm{Na}$ temat tego numizmatu por. I. Milewski, Soli invicto comes czy imperator christianissimus? Euzebiusz z Cezarei o pośmiertnej monecie Konstantyna Wielkiego, [w:] Florilegium. Studia ofiarowane Profesorowi Aleksandrowi Krawczukowi z okazji dziewięćdziesiątej piątej rocznicy urodzin, red. E. Dąbrowa, T. Grabowski i M. Piegdoń, Kraków 2017, s. 365-388. Z przekazu w Vita Constantini (IV,73) nie wynika, czy Euzebiusz z Cezarei opisywał solida (co jest bardziej prawdopodobne), czy może jednak bitego w brązie centenionalisa. W obydwu przypadkach interesujące nas przedstawienia na rewersie są identyczne. Bite w złocie solidy mają natomiast większą średnicę, przez co też ich ikonografia jest wyraźniejsza. 


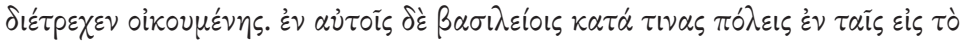

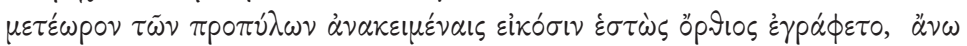

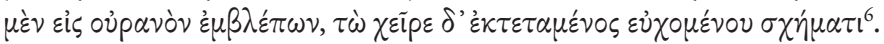

W polskim tłumaczeniu, autorstwa Teresy Wnętrzak powyższy tekst brzmi następująco:
Jak wielka była potęga Boskiej wiary, która przenikała głębię jego [Konstantyna - I. M.] duszy, poznać można, wnioskując z tego, że wy- dał nakaz, aby na złotych monetach wytłaczana była jego podobizna, gdy z oczyma wzniesionymi w górę wyciagga ręce do Boga jako ten, który się modli. Tak wybite monety rozchodziły się po całym świecie rzym- skim. Jego malowane naturalnej wielkości portrety zostały także umiesz- czone u szczytu bram wejściowych pałaców królewskich w niektórych miastach, jego oczy wpatrują się na nich w niebo, a ręce są rozpostarte w pozie modlitewnej ${ }^{7}$.

Nie ma i raczej nie było solida, ani też innej monety, Konstantyna Wielkiego opatrzonego przedstawieniem z awersu, o jakim czytamy w polskim tłumaczeniu tekstu. Porównanie tego przekładu z przytoczonym powyżej tekstem greckim uwidacznia jego niezgodność w najistotniejszym dla naszych dociekań passusie. W tym miejscu polskie tłumaczenie Żywota Konstantyna nie odpowiada brzmieniu greckiego tekstu Vita Constantini. Należy przy tym zaznaczyć, że analogicznie sytuacja kształtuje się również w przypadku tłumaczeń renomowanych edycji Vita Constantini opublikowanych w serii Sources Chrétiennes oraz w Fontes Christiani. Czy jest więc to błąd? Jest, nie mam w tej mierze żadnych wątpliwości. Kluczowe dla na-

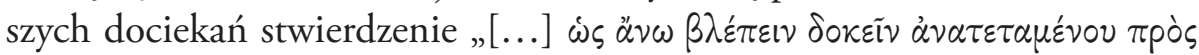

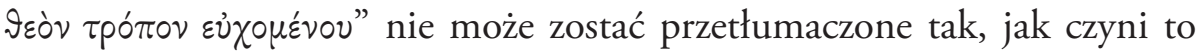
Teresa Wnętrzak, a mianowicie: „[...] gdy z oczyma wzniesionymi w górę wyciąga ręce do Boga jako ten, który się modli”. Prawidłowe brzmienie tego passusu, uwzględniające również oględziny numizmatów epoki kon-

6 Eusebius, Vita Constantini IV, 15, 1-16, s. 125-126.

7 Eusebius, Vita Constantini IV, 15, tł. T. Wnętrzak, [w:] Życie Konstantyna, Kraków 2007, s. 218. 
stantyńskiej, do których odnosi się powyższy opis (o czym poniżej), powinno brzmieć następująco:

„[...] jakby uniesiony, patrzył w górę, jak ktoś gorliwie modlący się do Boga”.

Z greckiego tekstu Vita Constantini wynika więc, że cesarz został zobrazowany na awersie solida „w modlitewnym uniesieniu”, w swego rodzaju religijnej ekstazie. On niczego, poza wzrokiem, nie podnosi w opisanym przedstawieniu, co innego prezentują wspomniane w dalszej części tekstu „malowane naturalnej wielkości portrety” Konstantyna zawieszane nad bramami pałaców, przedstawiające cesarza w pozie oranta (,jego oczy wpatrują się [...] w niebo, a ręce są rozpostarte w pozie modlitewnej”) ${ }^{8}$.

Zanim przejdę do analizy opisanego przez autora Vita Constantini numizmatu, chciałbym wskazać na prawdopodobne źródło „inspiracji” w dotychczasowych tłumaczeniach interesującego mnie passusu na języki nowożytne. Najprawdopodobniej jest nim łacińskie tłumaczenie tekstu zamieszczone w Patrologia Graeca. Czytamy w nim:

Quanta porro divinae fidei vis ac virtus in ejus animo insederit, vel ex hoc uno conjici facile potest, quod in aureis nummis exprimi se jussit vultu in coelum subiato, et manibus expansis instar precantis. Et hujus quidem formae nummi per universum orbem Romanum cucurrerunt. In ipsa vero regia juxta quasdam januas, in imaginibus ad ipsum vestibuli fastigium postis depictus est stans, defixis quidem in coelum oculis, manibus autem expansis pracantis in modum?

To właśnie w łacińskim tłumaczeniu Vita Constantini opublikowanym przez J. P. Migne’a, po raz pierwszy pojawiło się „dopowiedzenie”, iż cesarz na awersie opisanego solida modli się, wyciągając rozpostarte ręce ku górze, a więc, że został nań przedstawiony w pozie oranta. Tę nadinterpre-

8 Ibidem.

9 Eusebius, Vita Constantini IV, 15, Patrologia Graeca 20, col. 1163. 
tację interesującego nas tu passusu powtarzano w kolejnych przekładach Zywota Konstantyna ${ }^{10}$.

\section{Konfrontacja przekazu z Vita Constantini IV, 15 z ikonografią numizmatóu epoki konstantyńskiej}

Skoro ustaliliśmy już prawidłowe, jak mniemam, brzmienie interesującego nas passusu, skonfrontujmy go z ikonografią solidów bitych przez Konstantyna Wielkiego. Dokonamy analizy awersów tych numizmatów, jak również, co nie mniej istotne i chyba celowo przemilczane przez autora relacji, rewersów, które stanowią uzupełnienie przekazu ikonograficznego zasygnalizowanego na awersie. Opisane przedstawienie, wbrew zapewnieniom autora Vita Constantini, zdobiło nie tylko solidy Konstantyna Wielkiego, ale także jego silikwy ${ }^{11}$ i brązy ${ }^{12}$, jak również pieniądz opatrzony wizerunkami jego synów ze związku z Faustą (cezarów: Konstantyna, Konstancjusza i Konstansa) oraz ich kuzyna, Delmacjusza (o czym w dalszej części tekstu).

10 Eusèbe de Césarée, Vie de Constantini IV, 15,1, traduit par M. J. Rondeau, Sources chrétiennes 559, Paris 2013, s. 473: „sur les monnaies d'or il fit imprimer son effigie les yeux levés au ciel, les mains étendues vers Dieu, à la manière d'un orant”. W niemieckim tłumaczeniu interesującego nas passusu opublikowanym w prestiżowej serii Fontes Christiani czytamy: „Auf Goldmünzen ließ er sein eigenes Porträt in der Weise einprägen, daß er den Eindruck machte nach oben zu blicken nach Art eines Mannes, der mit ausgebreiteten Armen zu Gott betet" (Eusebius von Caesarea, Vita Constantini IV, 15, 1, übersetzt von H. Schneider, Fontes Christiani Bd. 83, Turnhout 2007, s. 427).

11 Por. P. M. Bruun, The Roman Imperial Coinage, vol. 7, Constantine and Licinius A.D. 313-337, London 1966: Konstantynopol 136A (dalej cyt. RIC 7); RIC 7, Antiochia 105 (rewers: Wiktoria idąca w prawo z wieńcem w prawej dłoni); ibidem, Antiochia 329

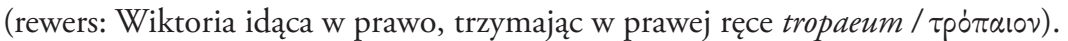

12 Por. chociażby: RIC 7 Konstantynopol 32 r. (rewers: Constantiniana Daphne); ibidem, Heraclea 92 (rewers: VOT/IS/ XX) oraz Heraclea 93 (rewers: w wieńcu VOT/ IS/ XXX oraz okalająca wieniec tytulatura: D/OMINVS/N/OSTER/ MAXIMVS AVG/ VSTVS/). Por. także brązy, których inskrypcja z rewersu bez wątpienia wskazuje na fakt, że zostały one wybite jeszcze za współrządów Konstantyna Wielkiego z Licyniuszem, por. RIC 7, Kyzikos 575 r. ??? oraz 353 (rewers: PRIVIDENTIAE AVGG/VSTORVM/). 
Przypomnijmy, że autor Vita Constantini opisuje w swym dziele wygląd awersu solida. Do naszych czasów dochowało się ich sporo. Są one datowane na lata 324-335. Większość z nich opatrzona jest na rewersie ikonografią o symbolice militarnej, przedstawiającą Konstantyna Wielkiego jako triumfatora. Dostrzegamy więc nań cesarza w rynsztunku bojowym kroczącego w prawo z włócznią w prawej ręce, w lewej zaś, niczym Mars, Konstantyn trzyma przerzucony przez ramię tropaeum ( $\tau \rho o ́ \pi \alpha \iota \mathrm{v})$. Po obydwu stronach kroczącego cesarza siedzą spętani jeńcy, całość zaś przedstawienia opatruje inskrypcja: GLORIA CONSTANTINI AVG(VSTI) ${ }^{13}$. Niemalże identyczne elementy ikonograficzne odnotowujemy również na rewersie semissa (pół solida): awers opatrzony przedstawieniem cesarza ze wzrokiem skierowanym ku górze, bez inskrypcji. Na rewersie przedstawiono cesarza z włócznią w lewej ręce, w prawej zaś trzymającego Victoriolę (posążek bogini Wiktorii na globie). Po obydwu stronach Konstantyna znajdują się jeńcy, a jednego z nich cesarz przygniata stopą do podłoża. Całość przedstawienia opatrzona jest inskrypcją: GLORIA CONSTANTINI AVG(VSTI) ${ }^{14}$. Najciekawszy spośród tych „militarnych” rewersów odnajdujemy w przypadku egzemplarza wybitego w Siscia. Na awersie dostrzegamy cesarza z mocno wyciągniętą „łabędzią” szyją, ze wzrokiem skierowanym ku górze. Natomiast na rewersie przedstawiono Konstantyna w bojowym rynsztunku, trzymającego w prawicy labarum. Całość przedstawienia opatruje inskrypcja: GLORIA SECVLI (sic!) ${ }^{15}$. Warto zaznaczyć, że jest to jedyny znany tego typu egzemplarz solida (zarówno w zbiorach prywatnych, jak też publicznych), obecnie przechowywany w Gabinecie Numizmatycznym Muzeum Narodowego w Belgradzie ${ }^{16}$. Wyżej omówione solidy to te najciekawsze egzemplarze $\mathrm{z}$ „militarną” ikonografią na rewersie. Kolejne, opatrzone na awersie przedstawieniem cesarza ze wzrokiem skierowanym ku górze, różnią się mało istotnymi detalami na rewersie ${ }^{17}$, choć jest jeden wyjątek, z nieco kuriozalną ikonografią. Przy standardo-

13 RIC 7, 163v (Tessalonika). Por. także P. Bastien, Monnaie et donativa au BasEmpire, Wetteren 1988, s. 80.

14 RIC 7, Nicomedia 151.

15 RIC 7, Siscia 207.

16 K.M. Girardet, Der Kaiser und sein Gott, s. 57, 94.

17 RIC 7, Ticinum 179. 
wym w tym przypadku przedstawieniu na awersie (cesarz z uniesionym wzrokiem, inskrypcja: CONSTANTINVS AVG/VSTVS/) na rewersie dostrzegamy siedzącą na tronie Wiktorię (na pewno jednak nie Romę, gdyż postać ta ma skrzydła), która trzyma w ręku koronującą ją wieńcem Viktoriolę $^{18}$. Niewykluczone, że przedstawienie to jest swego rodzaju „wariacją” autora menniczego stempla albo, czego nie można wykluczyć, jego błędem. $\mathrm{Na}$ rewersie kolejnego egzemplarza dostrzegamy Wiktorię na tronie i piszącą na tarczy trzymanej przez kupidyna: VOT(IS) XXX. To komunikat, jaki chciano upowszechnić pomiędzy odbiorcami pieniądza, iż właśnie minęła trzecia dziesięciolatka szczęśliwych i pełnych sukcesów rządów cesarza Konstantyna. Przedstawienie z rewersu opatrzone zostało inskrypcją: VICTORIA CONSTANTINI AVG(VSTI) ${ }^{19}$. Innym motywem na rewersach interesujących nas tu solidów to dwa wieńce z ośmioramienną gwiazdą powyżej (symbolem aeternitas, ale też kultów solarnych) ${ }^{20}$.

Przedstawienie opisane przez autora Vita Constantini znane jest również z awersów numizmatów synów Konstantyna Wielkiego: Konstantyna $^{21}$, Konstancjusza ${ }^{22}$ oraz Konstansa (ale tylko jako Augusta, a więc nie wcześniej jak od lata/wczesnej jesieni 337 roku) ${ }^{23}$, jak również ich kuzyna, Delmacjusza ${ }^{24}$. Warto zaznaczyć, że choć synowie Konstantyna tytułowani są na wspomnianych numizmatach jako NOBILISSIMI CAESARES, to są już przedstawiani z diademem na głowie ${ }^{25}$, także typu hellenistyczne-

18 RIC 7, Nicomedia 70.

19 RIC 7, Nicomedia 175.

20 RIC 7, Ticinum 192. Przedstawienie na awersie opatrzone inskrypcją: CONSTANTINVS AVG(VSTVS).

21 Cezar Konstantyn: RIC 7, 517 var; J. P. C. Kent, C. H. V. Sutherland, The Roman Imperial Coinage, Vol. 8: The Family of Constantine I, Cambridge 1981 (Siscia 229), dalej cyt. RIC 8. Konstantyn II (jako august): RIC 8, Siscia 229; RIC 8, Konstantynopol 15.

22 Cezar Konstancjusz: RIC 8, Konstantynopol 128 var; Konstancjusz II (August): RIC 8, Antiochia 34, 105; RIC 8, Kyzikos 2; RIC 8, Siscia 229.

23 Konstans August: RIC 8, Konstantynopol 19 var, 20.

24 Delmacjusz: RIC 7, Konstantynopol 136 A (siliqua).

25 R. Delbrück, Spätantike Kaiserporträts von Constantinus Magnus bis zum Ende des Westreiches, Berlin-Leipzig 1933, s. 56-58. 
go $(\tau \alpha \iota v i \alpha)^{26}$. Diadem na głowie panującego w dotychczasowej literaturze dotyczącej epoki konstantyńskiej to jeden z argumentów (choć dość wątpliwy) w ustalaniu chronologii pieniądza opatrzonego wizerunkiem Konstantyna Wielkiego. Póki co, za aktualne w tej mierze uchodzą ustalenia P. Bruuna zaproponowane w 1958 roku $^{27}$, po ujawnieniu w zbiorach monachijskiego Staatliche Münzsammlung srebrnego medalionu Konstantyna Wielkiego z chrystogramem na cesarskim hełmie, najprawdopodobniej wybitego z okazji decenaliów ${ }^{28}$. Ustalenia brytyjskiego uczonego sprzed 60 lat nie wytrzymują jednak próby konfrontacji z wieloma numizmatami epoki oraz postulowaną ostatnimi czasy potrzebą reinterpretacji „przełomu konstantyńskiego”. Innymi słowy, należałoby ponownie pochylić się nad chronologią monet epoki konstantyńskiej, a szczególnie nad chronologią „zniknięcia” z nich Sol Invictus.

\section{Analiza Vita Constantini IV,15}

W jakim celu oraz w jakim kontekście dla swego wywodu Euzebiusz z Cezarei przytacza opis interesującego nas tu solida? W jego mniemaniu modlitewna poza cesarza świadczyła o jego oddaniu dla prawdziwej religii, dla chrześcijaństwa, to zaś miało gwarantować długie i szczęśliwe rządy Konstantyna, a tym samym pomyślność wszystkich mieszkańców Imperium. W tym celu również „rozmodliło się” całe państwo, a cesarz ustanowił siódmy dzień tygodnia „dniem Pańskim”, tak aby szczególnie tego dnia oddawać cześć należną Bogu chrześcijan ${ }^{29}$. Powyższa wykładnia, w każdym z jej elemen-

26 M. Haake, Diadem und basileus. Überlegungen zu einer Insignie und einem Titel in hellenistischer Zeit, [w:] Das Diadem der hellenistischen Herscher. Übernahme, Transformation oder Neuschöpfung eines Herrschaftszeichens?, Hrsg von A. Lichtenberger, K. Martin, H. Nieswandt, D. Salzmann, Bonn 2012, s. 293-313.

27 P.M. Bruun, The Disappearance of Sol from Coins of Constantine, „Arctos” 1958, t. 2, s. 15-37.

28 RIC 7, Ticinum 36. Por. także K. Kraft, Das Silbermedaillon Constantins des Grossen mit dem Christusmonogram auf dem Helm, „Jahrbuch für Numismatik und Geldgeschichte” 1954/1955, t. 5/6, s. 151-178.

29 Eusebius, Vita Constantini IV, 18. 
tów, jest wątpliwa. Co nie mniej ważne, autor relacji, rzekomo Euzebiusz z Cezarei, nie trzyma się chronologii, łącząc pojawienie się na rynku pieniężnym opisanego przez siebie solida (nie wcześniej niż u schyłku 324 roku) z ustanowieniem przez cesarza Konstantyna święta „dnia Pańskiego”, w rzeczywistości święta venerabilis dies solis (321 rok) ${ }^{30}$. W czym upatrywać przyczyn pojawienia się tej niezgodności? Czyżby w nieznajomości faktów przez autora relacji, w braku orientacji w chronologii opisywanych wydarzeń? Jeśli tak, to byłby to kolejny argument kwestionujący autorstwo Vita Constantini w wersji znanej nam obecnie.

Aby właściwie ocenić opisane przez Euzebiusza przedstawienie Konstantyna Wielkiego z awersu jego solidów, należy zwrócić uwagę na oczywisty fakt, a mianowicie że sposób, w jaki cesarz został nań przedstawiony, jest ponadczasową pozą modlitewną znaną we wszystkich kulturach świata. Interesujące nas tu przedstawienie na awersach numizmatów nazywane jest „aleksandrowym”. Po raz pierwszy identyfikacji dokonał w latach trzydziestych zeszłego wieku Delbrück ${ }^{31}$. W numizmatyce antycznej wspomniany typ pojawił się po raz pierwszy na tetradrachmach bitych przez Kassandra ${ }^{32}$ oraz przez innych hellenistycznych władców, a mianowicie: trackiego Lizymacha ${ }^{33}$, Seleucydów (Seleukos I Nikator ${ }^{34}$, Antioch I Soter ${ }^{35}$, Antioch II

30 Codex Theodosianus 2,8,1. Por. także J. Rüpke, Die Geschichte der Repräsentation und religiösen Qualifikation von Zeit in Rom, Berlin 1995, s. 462; K.M. Girarded, Linvention du dimanche: du jour du soleil au dimanche. Le dies Solis dans la législation et la politique de Constantin le Grand, [w:] Empire chrétien et Église aux IVe et Ve siècles. Integration ou "concordat"? Le témoignage du Code Théodosien, eds J.N. Guinot, F. Richard, Paris 2008, s. 341-370.

31 R. Delbrück, Spätantike Kaiserporträts, s. 56.

32 M.J. Price, The Coinage in the Name of Alexander the Great and Philip Arridaeus, Zürich-London 1991 (nr 468).

33 M. Thompson, The Mints of Lysimachus, [w:] C.M. Kraay, G.K. Jenkins, Essays in Greek Coinage presented to Stanley Robinson, Oxford 1968, 163-182 (nr 212); K. Dahmen, The Legend of Alexander the Great on Greeks and Roman Coins, London - New York 2007, s. 16-17, 42-49, 119-120.

34 K. Dahmen, The Legend of Alexander the Great, s. 10, 14-15, 117-118.

35 A. Houghton - C. Lorber, Seleucid Coins, New York 2002, nr 379, 3a (dalej cyt. SC); E.T. Newell, The Coinage of the Eastern Seleucid Mints, New York 1938, 154, 177. 
Theos $^{36}$, Demetrios I Soter ${ }^{37}$ ), Ptolemeuszy (Ptolemeusz I Soter ${ }^{38}$, Kleopatra III z Ptolemeuszem X Alexandrem ${ }^{39}$, Ptolemeusz XII Neos Dionizos ${ }^{40}$ ) oraz Mitrydatesa VI Eupatora ${ }^{41}$. To władcy, którzy rościli sobie prawo do schedy po Aleksandrze, snuli plany odbudowy jego monarchii albo też, jako „ponowne wcielenie” Aleksandra i obrońcy czy wręcz „wyzwoliciele” Greków, próbowali przegnać ze Wschodu Rzymian (Mitrydates VI Eupator). Wizerunki Aleksandra w modlitewnej pozie zdobiły także tzw. koinony, brązy miast rzymskiej Macedonii cieszących się autonomią w okresie Wczesnego Cesarstwa ${ }^{42}$. „Nowym Aleksandrem” nazywali siebie również rzymscy dowódcy schyłku Republiki walczący na Wschodzie (Lukullus, Pompejusz, Cezar), ale przede wszystkim cesarze, którzy odnieśli sukcesy w starciu z Persami, zarówno polityczne (Oktawian August), jak też militarne, chociażby Neron (kampanie Korbulona w Armenii), Trajan, Marek Aureliusz, Septymiusz Sewer czy też Galeriusz. Analogicznie rzecz miała się w przypadku Juliana Apostaty, który wyruszył na państwo perskie (wyprawa zakończona jednak klęską ${ }^{43}$. Niewykluczone, że podobnie stylizował się

36 SC 587, 1a, 4b; O. Hoover, The Handbook of Greek Coinage Series, London 2012, 9, 236g (dalej HGC).

37 SC 1638, 1i; SMA 97; O. Hoover, Handbook of Syrian Coins, Lancaster-London 2009, 795 i n.; Antioch VII (A. Houghton, A. Spaer, C. Lorber, Sylloge Nummorum Graecorum Israel I. The Arnold Spaer Collection of Seleucid Coins The Arnold Spaer Collection of Seleucid Coins, Jerusalem 1998, 1872-1874 (dalej cyt. SNG Spaer); Kleopatra Thea i Antioch VIII (SC 2271,1).

38 L. Svoronos, Ta nomismata tou Kratous ton Ptolemaion, Athenai 1904, 185 (dalej cyt. Svoronos); Sylloge Nummorum Graecorum, Dänmark. The Royal Collection of Coins and Medals, Copenhagen 1945, 44 (dalej cyt. SNG Cop.).

39 Svoronos, 1728; SNG Cop. 359.

40 Svoronos 1837; SNG Cop. 395.

41 F. De Callataÿ, L'histoire des guerres mitridatiques vue par les monnaies, Louvain-LaNeuve 1997 (D5); K. Dahmen, The Legend of Alexander the Great, s. 14-20, 43, 60.

42 SNG Cop. 1369 var, 1378 var; H. Gaebler, B. Pick, Die antiken Münzen Nordgriechenlands, Bd. 3, Makedonia und Paionia, Berlin 1995 (618 var, 683); K. Dahmen, The Legend of Alexander the Great, s. 31-33, 35-37, 39-40, 42-47, 60-62.

43 H.P. Laubscher, Der Reliefschmuck des Galeriusbogens in Thessaloniki, Berlin 1975, s. 26; A. Kühnen, Die imitatio Alexandri in der römischen Politik (1.Jh.v.Chr. bis 3. Jh.n.Chr.), Münster 2008, s. 176 i n.; A. Demandt, Alexander der Grosse. Leben und Legende, München 2009, s. 441. 
również Konstantyn. Opisane przez autora Vita Constantini przedstawienie jest więc nie tylko gestem modlitewnym, towarzyszy mu głębszy zamysł. Najprawdopodobniej więc cesarz, opanowawszy Wschód (po ostatecznym pobiciu Licyniusza w 324 roku), dostrzegł w sobie „nowego Aleksandra”, przed którym stoją kolejne wyzwania: jeśli nie podbój Wschodu, to przynajmniej zneutralizowania płynącego stamtąd zagrożenia ze strony Persów. Mimo że wielu, jeśli nie większość, rzymskich władców uważało się za „nowego Aleksandra”, to o ile mi wiadomo, analogiczne do opisanego przez autora Vita Constantini przedstawienie cesarza nie pojawia się na żadnym numizmacie przed Konstantynem ${ }^{44}$. Natomiast pojawia się ono na złotym medalionie $\mathrm{z}$ wizerunkiem Aleksandra Macedońskiego odnalezionym w 1902 roku w egipskim Abukirze. Inne zlokalizowane w tym skarbie numizmaty pozwoliły na datowanie tego medalionu na lata 215-249, a więc na okres od panowania Karakali (w 215 roku cesarz przygotowywał już wyprawę na Wschód) do ostatniego roku panowania Filipa I Araba, władców prowadzących intensywną politykę perską ${ }^{45}$. Po Konstantynie nie odnotowujemy już sięgania w mennictwie rzymskim po „stylizację” panującego na Aleksandra Macedońskiego, co było związane z postępującą chrystianizacją przedstawiania cesarskiego majestatu.

\section{Zakończenie}

Omówiony powyżej opis solida, przedstawienie rzekomo pogrążonego w modlitwie cesarza Konstantyna, miał w ujęciu autora Vita Constantini

44 Zaliczanie do tej grupy monet opatrzonych wizerunkiem Nerona lub też Galiena jest nieuprawnione. W obydwu przypadkach mamy najprawdopodobniej do czynienia z wolem tarczycowym, skrzętnie skrywanym pod zarostem, a nie z „łabędzią” szyją charakterystyczną dla interesujących nas numizmatów epoki konstantyńskiej.

45 M. Müller, Die Münzen des Altertums, München 1933, s. 172 (Tafel XXXI). Por. także nowsza literatura na temat tego medalionu: C. Vermeule, Alexander the Great, the Emperor Severus Alexander and the Aboukir Medallions, "Schweizerische Numismatische Rundschau" 1982, t. 61, s. 64; K. Dahmen, The Legend of Alexander the Great, s. 35-38, 45-46, 62-63, 143-152; idem, Alexander in Gold and Silver. Reassessing Third century AD Medallions from Aboukir and Tarsos, „American Journal of Numismatics” 2008, t. 20, s. 493-546. 
propagować wizerunek pobożnego chrześcijańskiego władcy, którego oddanie dla „prawdziwej religii” gwarantowało również pomyślność jego rządów, a tym samym szczęśliwy i spokojny czas dla całego Imperium. Tymczasem analiza tej relacji połączona z oględzinami opisywanych przez Euzebiusza numizmatów, solidów jak również silikw oraz brązów epoki konstantyńskiej (o których autor relacji już nie wspomina) pozwala kwestionować to przekonanie. W ocenie tego przedstawienia nie należy podążać tropem wytyczonym przez autora Vita Constantini. Nie można wykluczyć, że rzeczywiście potwierdza ono głęboką religijność cesarza. Można natomiast mieć wątpliwości w ocenie jej charakteru, a mianowicie czy cesarz rzeczywiście był (tak jak usiłuje przekonać czytelnika Euzebiusz z Cezarei oraz zależni od niego autorzy) chrześcijańskim monoteistą? Raczej wątpię, a do obstawania przy tych wątpliwościach upoważnia przede wszystkim ikonografia bitego przez niego pieniądza oraz racjonalna ocena relacji źródłowych obrazujących jego panowanie. Jest przy tym wielce prawdopodobne, iż „program menniczy”, którego elementem było opisane przez Euzebiusza przedstawienie z awersu solida, poza symboliką religijną sygnalizował również plany cesarza zorganizowania wyprawy przeciwko państwu perskie$\mathrm{mu}^{46}$. I rzeczywiście o takim zamiarze wspomina autor Vita Constantini, choć przyczyn perskiej polityki Konstantyna upatruje on w „konieczności” wzięcia w obronę perskich chrześcijan „prześladowanych” przez Sappora $\mathrm{II}^{47}$. Przypisanie nieprzyjacielowi winy za wybuch wojny, interwencja w obronie represjonowanych poddanych, w tym także rzekomo „tępionych” chrześcijan, to stały element w polityce cesarza Konstantyna eksponowany przez autora Vita Constantini zarówno w wojnie z Maksencjuszem (w 312 roku $)^{48}$ jak też w przypadku obydwu wojen z Licyniuszem (w 316

46 A. Luther, Konstantins letzte Pläne. Die „unvollendete Persienexpedition”, [w:] K. Ehling, G. Weber, Konstantin der Große zwischen Sol und Christus, Mainz 2011, s. 116.

47 T.D. Barnes, Constantin and Eusebius, Cambridge-London 1982, s. 258-259; idem, Constantine and the Christians of Persia, „Journal of the RomanStudies”1985,t.75, s. 126-136; K. Smith, Constantine and the Captive Christians of Persia. Martyrdom and Religious Identity in Late Antiquity, Oakland 2016, s. 17-47, 181-184.

48 Eusebius, Vita Constantini I, 26, 33-38. 
i 324 roku $)^{49}$. Innymi słowy, głęboko religijny cesarz Konstantyn (co do tego nie mam wątpliwości, poza charakterem tej „religijności”) najprawdopodobniej przygotowywał się do kolejnej wojny, tym razem z Persją, na którą wyruszył pod znakiem chryzmy (chroniącej „w walkach z nieprzyjaciółmi”" ${ }^{50}$. Tak też Konstantyn Wielki został przedstawiony na rewersie omówionego powyżej solida z Muzeum Narodowego w Belgradzie. Tylko nagła i ciężka choroba, jaka spadła nań na początku wyprawy, a w jej skutek śmierć, uniemożliwiły cesarzowi realizację tego zamierzenia.

49 Licyniusz nazywany jest przy tej okazji przez autora Vita Constantini (I, 49) „okrutną bestią, która zaczaiła się, aby dręczyć Kościół Boży i innych mieszkańców prowincji” (tł. T. Wnętrzak, s. 127).

50 Tymi słowy „moc” chrystogramu noszonego przez cesarza i jego wojsko określa autor Vita Constantini (I, 29) w przededniu bitwy przy moście mulwijskim. Por. także ibidem I, 31: „Cesarz stale używał tego znaku zbawienia (chrystogramu) w charakterze środka obrony przed wszystkimi wrogami i nieprzyjacielskimi potęgami; rozkazał, aby inne, podobne do tego znaki, były noszone przed każdą armią” (tł. T. Wnętrzak, s. 118). 